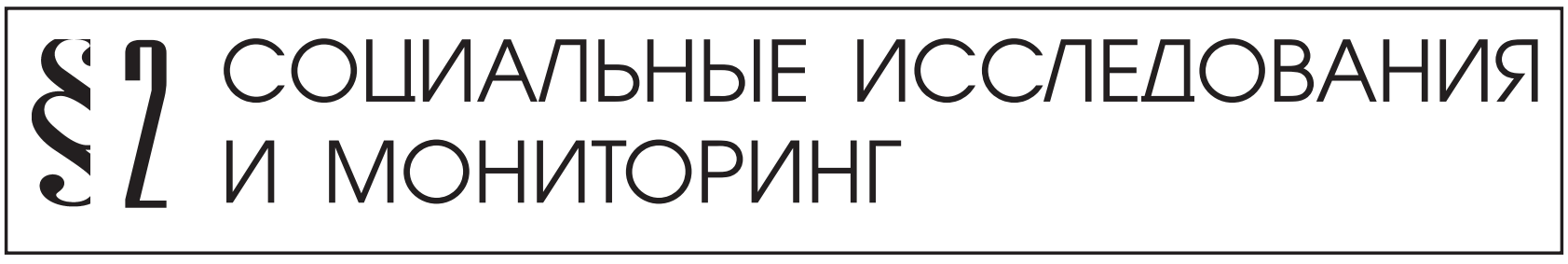

Трофимова И.Н.

\title{
СОЦИОКУЛЬТУРНЫЙ И ПОСЕЛЕНЧЕСКИЙ ФАКТОР В СОЦИАЛЬНО-ЭКОНОМИЧЕСКОМ РАЗВИТИИ ТЕРРИТОРИАЛЬНЫХ СООБЩЕСТВ
}

Аннотация: В статье анализируется влияние социокультурного и поселенческого фактора в свете возможности и перспектив модернизации жизнедеятельности территориальных сообществ. Актуальность проблемы обусловлена сущуествующчми в российском обществе ценностными различиями и противоречиями, а также глубоким социально-территориальным неравенством и межпоселенческой дифференцииацией. Особое внимание уделено анализу специффики проявления традиционалистских и модернистских ценностных ориентаций и поведенческих установок россиян в зависимости от типа поселения. Рассмотрены противоречивые эффекты модернизации относительно территориального развития странь в иелом. Анализ проблемьл учитывает основные положения теории модернизации относительно трансформации социокультурньхх оснований современного общества, позволяющие конщептуализировать комплексное влияние социокультурного и поселенческого фактора на развитие территориальных сообществ. Территориальное сообщество рассматривается как сложная саморазвиваюшаяся система, функиионирование и развитие которой зависит от многих факторов. Комплексное влияние социокультурного и поселенческого фактора обусловливает различие ценностных ориентаций россиян, что, в конечном счете, определяет специфику социально-экономического развития отдельных территориальных сообществ и территориального развития страны в целом.

Review: The author of the article analyzes the influence of the socio-cultural factor and the factor of settlements in terms of opportunities and prospects of modernizing the activity of territorial communities. The importance of the topic is caused by the differences and contradictions in the values of the Russian society as well as a deep social inequality, territorial disparity and inter-settlement differentiation. Special attention is paid to the analysis of peculiarities of traditional and modernistic values and behavioral stereotypes of Russians depending on a type of settlement. The author also views contradictory effects of modernization regarding the territorial development of the country in general. Analyzing the problem, the author takes into account the main provisions of the theory of modernization regarding transformations of socio-cultural grounds of a modern society which allows to conceptualize integrated influence of the socio-cultural factor and the factor of settlements on the development of territorial communities. A territorial community is viewed as a complex self-development system which performance and development depend on many factors. The integral influence of the socio-cultural factor and the factor of settlements causes the difference in values of Russian people which, finally, defines creates special features of the social and economic development of independent territorial communities and territorial development of the country in general.

Ключевые слова: Территориальное сообщество, социиально-экономическое развитие, модернизация, соцүиокультурный фактор, поселенческий фактор, иченности, иченностные ориентации, социальное неравенство, территориальное неравенство, межсоселенческая дифференииация.

Keywords: Territorial community, social and economic development, modernization, socio-cultural factor, factor of settlements, values, value priorities, social inequality, territorial disparity, differentiation between settlements.

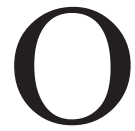
дним из важнейших условий социальноэкономического развития России является модернизация экономики, общественных и политических институтов, что, безусловно, предъявляет определенные требования к личности и социуму. Модернизация означает переход от абсолютных норм и ценностей к ценностям растущей рациональности, толерантности, доверия и уча- 
стия ${ }^{1}$, что предполагает формирование новой модели поведения, ориентированной на рыночную экономику, динамические процессы, индивидуализм и персональные достижения. В результате функционирования подобной модели снижается зависимость индивидов и общественных групп от государства, которое начинает восприниматься не как сила, стоящая над обществом, а как особый институт, выполняющий организационно-управленческие функции на принципах общественного договора. Создается законодательная база, защищающая частную собственность и предпринимательство, закрепляющая демократические свободы, права граждан на самоорганизацию и самоуправление, в том числе и в рамках местных территориальных сообществ.

В основе данных процессов и явлений лежат экономические, социальные и культурные изменения, что нашло свое отражение и в части российского истеблишмента. Появился запрос на социально-политическую модернизацию, смыслом которой объявлялось становление предельно открытой, гибкой и внутренне сложной политической системы, адекватной динамичной, подвижной, прозрачной и многомерной социальной структуре, отвечающей культуре свободных, обеспеченных, критически мыслящих, уверенных в себе людей ${ }^{2}$. И все же основным субъектом модернизации в нашей стране по-прежнему остается государство. Большая часть россиян не готова воспринимать общество в его автономности от политических институтов как самодеятельную и самоуправляемую сущность, исходную для всех других функций и образований, принципиально первичную структуру, в которой реализуются основные жизненные интересы человека. Еще большие трудности связаны с осознанием интересов территориальных сообществ. В глазах россиян именно государство как выразитель общих интересов должно, принимая во внимание интересы различных субъектов, на базе общественного консенсуса проводить политику, направленную на благо народа как единой общности ${ }^{3}$.

\footnotetext{
${ }^{1}$ Inglehart R., Baker W.E. Modernization, cultural change, and the persistence of traditional values // American sociological review. 2000. Vol.65. February. P.19-21.

${ }^{2}$ Медведев Д. Россия, вперед! // Российская газета. № 4995 (171). 2009. 11 сентября.

${ }^{3}$ Куда ведет кризис культуры? Опыт междисциплинарных диалогов / Под общ. ред. И. Клямкина. М.: Новое литературное обозрение, 2011. С.308-309.
}

При этом традиционализм общественного сознания нередко рассматривается как тормоз модернизации, как причина отставания от развитых стран и, как следствие, противопоставляется ценностям современного общества. Между тем существует определенное противоречие между целями модернизации, с одной стороны, и теми объективными условиями, которые существуют в каждом отдельно взятом обществе, с другой. В то время как технологические достижения, коммуникации и глобальный рынок способствуют распространению передовых идей, каждое сообщество имеет свой специфический ответ в виде комбинации собственного институционального и культурного наследия и институциональных и культурных моделей, привнесенных извне. Глобальная модернизация способствует объединению людей поверх географических границ, государств, социальных классов, идеологий, религий, национальностей и этносов и одновременно погружает человечество в водоворот постоянной дезинтеграции и обновления, борьбы и противоречий, двусмысленности и неопределенности ${ }^{4}$.

Противоречивое влияние модернизации особенно заметно в условиях нашей страны в силу чрезвычайного разнообразия форм и способов организации местной жизни, а также последствий радикальных социально-политических преобразований, приведших к ценностному расколу общества, росту социального и территориального неравенства. Территориальное неравенство фактически стало причиной того, что жизненные перспективы людей сегодня во многом определяются местом их проживания и теми возможностями, которые существуют на данной территории для развития человеческого потенциала. Так, в 2013 г. лишь в 10 российских регионах индекс развития человеческого потенциала превышал средний по стране уровень $(0,843)$ : Москва, Санкт-Петербург, Тюменская, Сахалинская, Белгородская и Томская области, республики Татарстан, Коми, Саха (Якутия) и Красноярский край. Немногим более $20 \%$ населения России живет в относительно благополучных регионах (в т.ч. $8 \%$ в Москве), около $10 \%$ - в регионах-аутсайдеpax, а более $2 / 3$ - в регионах со средним уровнем человеческого развития. Но и в самих регионах отмечается существенный разрыв в уровне и качестве жизни жителей отдельных поселений, например, между региональными столицами и малонаселенными удален-

${ }^{4}$ Berman M. All that is Solid Melts Into Air: The Experience of Modernity. NY: Simon and Schuster, 1983. P.15. 


\section{Политика и общество 6 (114) • 2014}

ными районами. Даже в более плотно заселенной европейской части масштабы экономической отсталости составляет более $40 \%$ территории, что является существенным тормозом для модернизации периферии ${ }^{5}$.

Между тем успешное функционирование и развитие территориальных сообществ зависит от их способности адаптироваться к изменяющимся условиям, включая способность формулировать адекватные вызовам времени цели и задачи своей жизнедеятельности. Россия является государством, где центр, регионы, столица и провинция всегда имели не только географические, но социокультурные особенности, что способствовало формированию у жителей разных типов поселений различное мироощущение и связанные с ним ценностные ориентации. Вторичный анализ результатов исследований, проведенных Институтом социологии РАН в 2012-2014 гг., показывает, что специфика ценностных ориентаций россиян во многом обусловлена существенными различиями в условиях и образе жизни на местах.

В условиях социально-территориального неравенства жители отдельных типов поселений поразному воспринимают происходящие процессы и явления, ощущают свое место и роль в жизни локального сообщества и страны в целом. Все это создает определенные трудности для формирования общего ценностного пространства как упорядоченной и осмысленной картины мира, на основе которой отбираются средства и цели деятельности, происходит согласование действий людей, осуществляется социальное регулирование. Какими бы ни были общие правила той или иной социальной деятельности, они всегда будут деформированы местными условиями. В качестве этих условий рассматриваются менталитет местного населения, сформированный под влиянием местных обстоятельств, включая уровень самочувствия и удовлетворенности жизнью в целом и отдельными ее сторонами, степень доверия политическим и общественным институтам, возможности самореализации.

Одним из следствий межпоселенческой дифференциации является различие в оценках текущей ситуации в стране. Результаты проведенного исследования показывают не большое, но все-таки преобладание негативных оценок. Так, положительно оценивают сложившуюся ситуацию не более $40 \%$ россиян. Как напряженная, кризисная представляется ситуация для $44 \%$ и как катастрофическая - для 8\% опрошенных респондентов, и $8 \%$ респондентов затруднились ответить на вопрос. Показательным является существенное различие в оценках жителей в зависимости от типа поселений: ситуация выглядит более позитивной для жителей мегаполисов, чем малых городов и сельской местности (см. рис. 1).

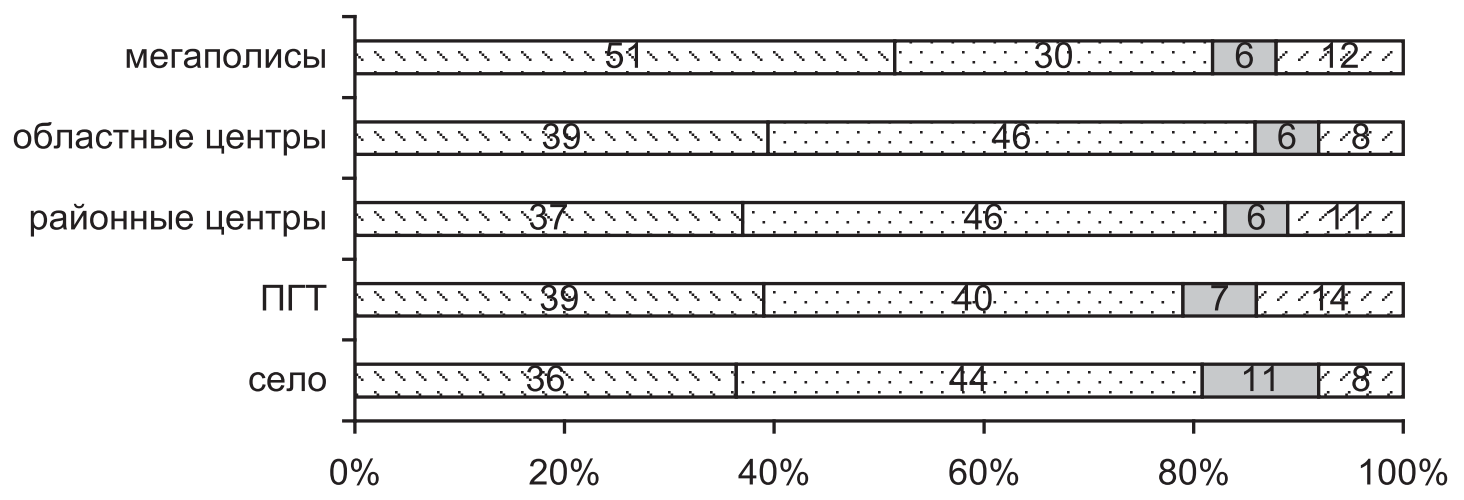

\section{$\square$ Ситуация нормальная, спокойная $\square$ Ситуация напряженная, кризисная \\ 口Ситуция катастрофическая $\square$ Ватруднились ответить}

Рис. 1. Оценка нынешней ситуации в России в цุелом, \%

\footnotetext{
5 Зубаревич Н. Модернизация и российское пространство // Доклад о развитии человеческого потенциала в Российской Федерации за 2011 г. / под ред. А. Аузана и М. Бобылева. М.: ПРООН в РФ, 2011. С.130-141.
} 
Отношение граждан к существующей ситуации во многом зависит от того, какие сферы жизни являются для них наиболее значимыми и как они характеризуются применительно к конкретным условиям того или иного типа поселения. Наиболее важной для россиян в целом сегодня является сфера финансового благополучия, в качестве таковой ее отметили 93\% опрошенных респондентов. Однако это не значит, что россияне в подавляющем своем большинстве поклоняются «золотому тельцу», скорее, они поставлены в такие условия, когда фактор финансового благополучия становится определяющим для состояния многих других сторон жизни. Об этом говорит и тот факт, что следующей по значимости сферой жизни идет поддержание дружеских отношений и различных форм общения, а также востребованность и признание со стороны общества.

Перспектива достижения финансовой независимости, в свою очередь, связана с повышением социального статуса и устойчивости социальных взаимосвязей, включая наличие работы или бизнеca, карьерное продвижение, поддержание значимых социальных отношений, сохранение здоровья и т.п. Примечательно, что значение образования оказывается далеко не в первом ряду. Возможность самореализации видится, прежде всего, в сочетании как коллективных (быть полезным обществу, следование общественным нормам), так и индивидуальных (жить интересной жизнью) интересов. Любопытным в этом плане является соотношение потребности жить в более справедливом и разумно устроенном обществе и готовности участвовать в общественно-политической жизни. Притом что $87 \%$ опрошенных респондентов заявили о своей потребности жить в более справедливом и разумно устроенном обществе, только 24\% указали на важность для них сферы общественно-политической жизни. В этом проявляется не только традиционный патернализм россиян, но и до сих пор не сформировавшееся общественное представление о взаимообусловленности уровня жизни, качества публичных институтов и активной гражданской позиции.

Степень важности отдельных сфер жизни для россиян также связана с типом поселения, в котором они проживают (см. рис. 2). Фактор финансового благополучия оказывается доминирующим и в данном случае, но вместе с тем обнаруживается ряд характерных особенностей, позволяющих раз- личать структуру жизненных приоритетов в разрезе типов поселений. Методологическим приемом может служить выделение «уравнительных» и «достижительных» приоритетов. При некоторой аналогии с терминальными (конечная цель индивидуального существования стоит того, чтобы к ней стремиться) и инструментальными (определенный образ действий или свойство личности является предпочтительным в любой ситуации) ценностями [9, р. 48], данный подход, на наш взгляд, в большей степени учитывает восприятие людьми специфики окружающего их социального пространства. «Достижительные» приоритеты (бизнес, карьера) характерны в первую очередь для жителей мегаполисов, в то время как жители провинциальных городов и поселков делают выбор в пользу коллективистских составляющих своей жизни (семья, дружба, социальная справедливость). И даже образование и здоровье здесь рассматриваются скорее сквозь призму равенства в доступности социальных услуг, нежели как условие карьерного или статусного роста. В этом обнаруживается принципиальное различие в моделях ценностных ориентаций и социального поведения жителей мегаполиса и провинции.

Для жителей мегаполисов решение социальных вопросов определяется возможностью достижения определенного статуса, позволяющего моделировать социальные отношения, исходя из индивидуальных или групповых предпочтений, связанных с принадлежностью к определенному социальному слою. Здесь прослеживается возможность индивидуального социального конструирования - представлений, статуса, отношений. Для жителей провинциальных городов и поселков индивидуальная результативность по своей важности стоит после коллективных интересов. Причастность семье, коллективу, местному сообществу формирует почву для большей готовности участвовать в решении проблем, значимых для всех. Притом, что из всех рассматриваемых сфер жизни респонденты меньше всего интересуются общественно-политической деятельностью, все-таки именно жители сел и малых городов проявляют к ней больший интерес, а наименьший - жители мегаполисов. По крайней мере, близость власти на низовых уровнях остается важным фактором гражданского участия, прежде всего, в различных практиках местного самоуправления. 


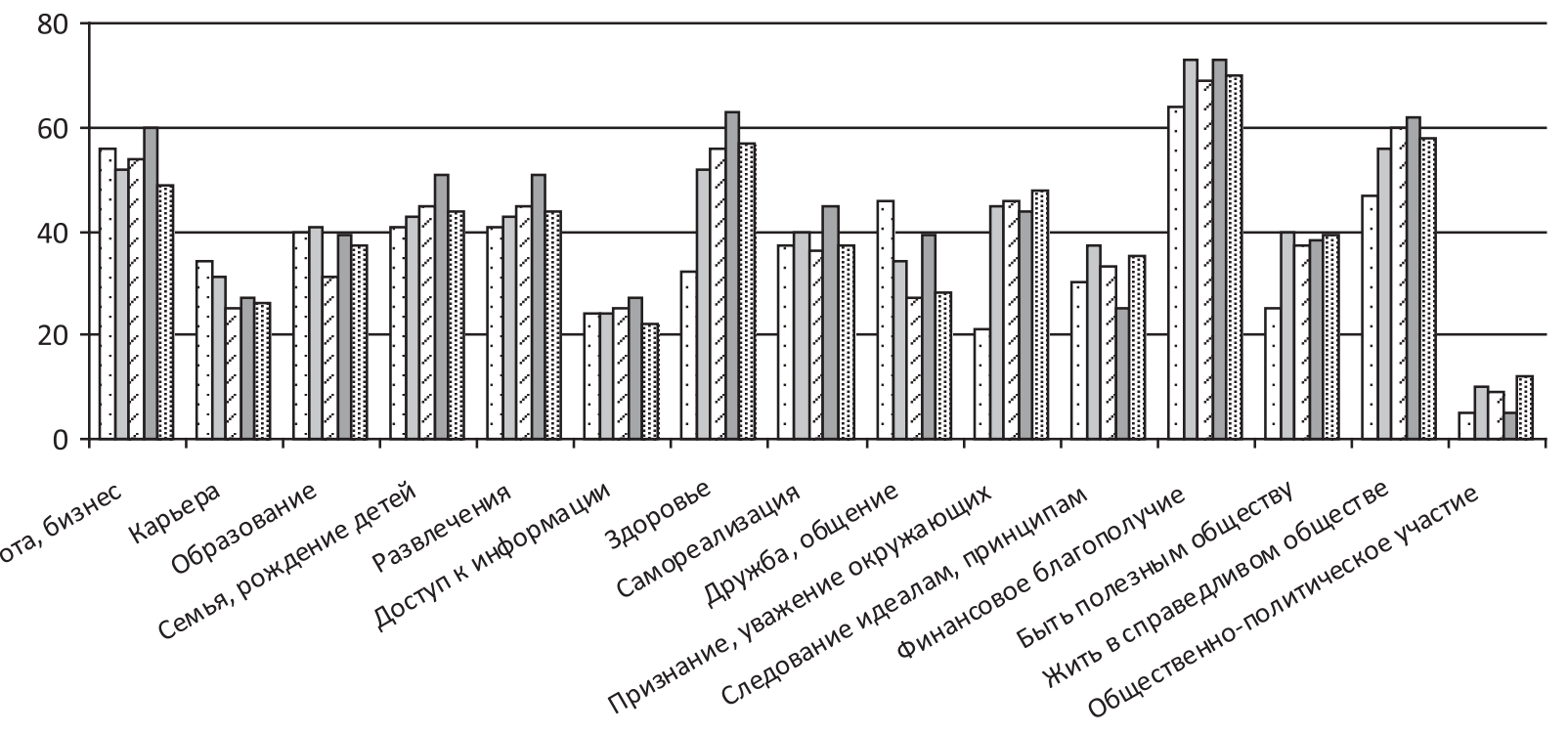

$\square$ мегаполисы $\square$ областные центры $\square$ районные центры $\square$ пГт

Рис. 2. Наиболее важные, с точки зрения россиян, сферы жизни, \%

Оценки состояния отдельных сторон жизни связаны также с осмыслением масштабов изменений. По мнению россиян, какие-либо позитивные изменения мало коснулись большинства населения, немногим лучше по этому параметру оценивается возможность участия в общественно-политической жизни (15\%). Также на общем фоне выделяется мнение о том, что возможность улучшения материального благополучия была лишь у ограниченного круга людей (38\%), очевидно, что за этим стоит недовольство граждан ростом материального расслоения общества. С точки зрения сужения возможностей для большинства, то негативно оцениваются, прежде всего, перспективы получения хорошего образования (27\%).

Что касается различий по типу поселений, то в глазах жителей мегаполисов сдвиги для большинства населения коснулись сферы участия в общественно-политической жизни, материального благополучия, профессионального роста и карьеры (см. рис. 3). Сельчане наравне с ростом материального благополучия отмечают также возможность заниматься предпринимательством.
А вот возможность получения хорошего образования для большинства населения достаточно низко оценивается жителями всех типов поселений. Обращает на себя внимание отмеченная жителями села возможность заниматься предпринимательством, однако причиной тому послужило не столько развитие социально-экономического потенциала сельских поселений, сколько помощь со стороны государства. Возможность заниматься предпринимательством для сельчан имеет больше значение, что в известной степени сближает их с жителями мегаполисов, только для первых предпринимательство носит аграрный, а для вторых - по большей степени интеллектуальный характер. Позитивному сдвигу в структуре сознания селян, росту оптимистических настроений в немалой степени способствовала реализация национального проекта «Развитие АПК», нацеленного на развитие личного подсобного хозяйства, организацию кооперативов по закупке сельхозпродукции у населения и т.п. - все это привело к росту занятости и повышению доходов сельского населения. 


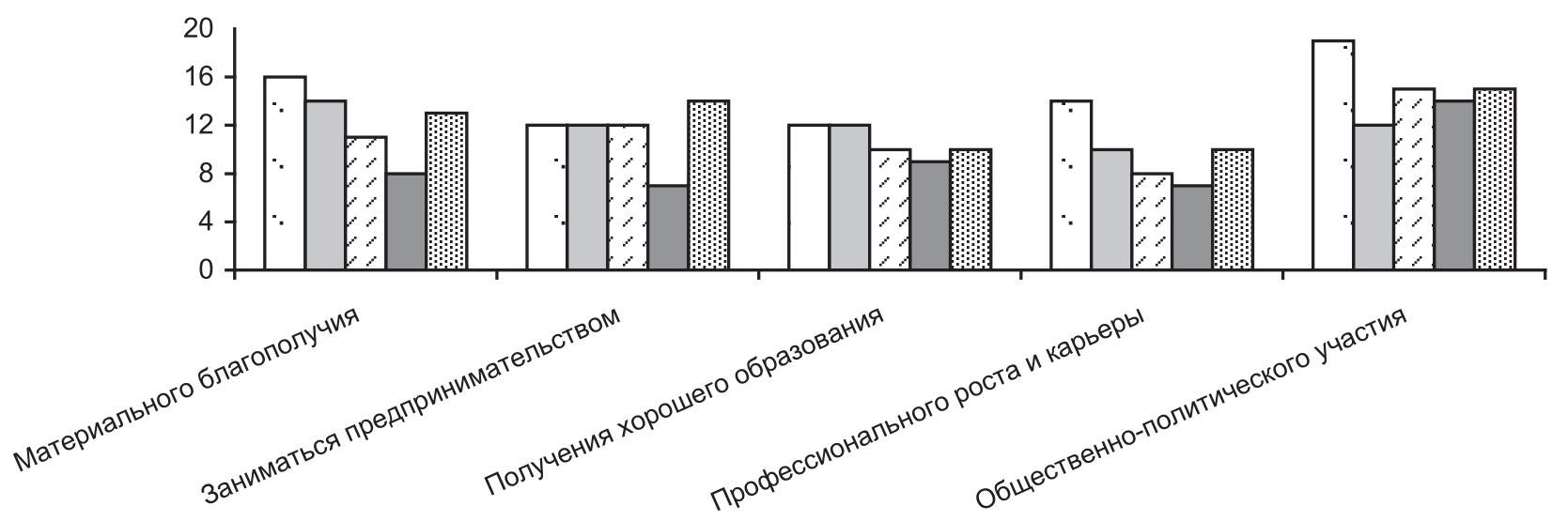

口Мегаполисы 口Областные центры 曰Районные центры 口Поселки городского типа 国 Село

Рис. 3. Оиенка россиянами изменений в отдельных сферах жизни, \%

Сравнение и ранжирование по степени значимости оценок отдельных сторон жизни жителями различных типов поселений позволило увидеть, что мегаполис фактически представляет собой отдельную ценностную модель, отличную от всех остальных. В известной степени, «различие между городом и деревней» в современной России уже является не столь актуальным. Гораздо большее значение имеет различие между мегаполисным типом поселения, с одной стороны, и остальными типами поселения, с другой, включая областные и районные центры, поселки городского типа и село. Поэтому можно говорить не о четырех или пяти ценностных моделях в соответствии с существующими типами поселений, но лишь о двух - мегаполисной (подразумевая агломерации Москвы и Санкт-Петербурга) и противостоящей ей «провинции», к которой можно отнести и ряд региональных центров, чья роль обусловлена преимущественно административным статусом. Наконец, важным оказывается и то, как преломляются ценностные модели в представлениях о необходимом условии для развития демократии в России. Для жителей мегаполисов таким условием выступает высокий уровень экономического развития, для жителей других типов поселений - равенство всех перед законом.

Выделение мегаполиса как особой модели ценностных ориентаций россиян имеет комплексный ха- рактер. Мегаполис воплощает особый тип ментальности, для которого характерны индивидуализм, рациональность, свобода выбора. Концентрация и высокая плотность населения, дифференцированная социально-профессиональная и нередко этническая структура, многообразие стилей жизни, культурных стереотипов, ценностных ориентаций - все это обусловливает специфику образа жизни, мышления и поведения современного жителя мегаполиса. В социальных взаимодействиях значительную долю занимают избирательные контакты, носящие рациональный и функциональный характер. Высокая плотность информационных потоков дает возможность, а чаще уже вынуждает человека делать самостоятельный индивидуальный выбор. В современном информационно-сетевом обществе на первый план выходят именно внутренние, субъективные, а не коллективные, параметры социального взаимодействия, что еще больше усиливает гетерохронность социального пространства.

Возможность объединения сельских поселений, малых, средних и даже крупных городов в одной модели ценностных ориентаций обусловлена не столько специфическим чертами, сколько их общим отличием от мегаполисного типа организации социальной жизни. Провинциальные поселения отличаются большей стабильностью в составе жителей, меньшей социально-профессиональной и куль- 


\section{Политика и общество 6 (114) • 2014}

турной дифференциацией. Отсутствие больших социальных и культурных различий между жителями, немногочисленность реальных и возможных контактов делают общение довольно тесным и охватывающим все стороны жизни. Особенно близки в своей ментальности жители сел и малых городов: стабильность, устойчивость социальных взаимодействий здесь ценятся много выше, чем успех в карьеpe, склонность к инерции сильнее, чем к развитию.

Безусловно, между отдельными типами поселений, противопоставленных в логике данного исследования мегаполису, существует множество различий, но тем более отчетливой становится проблема поляризации социального пространства России, когда речь идет о немногих точках инновационного развития (а в случае мегаполисов - и просто единичных) и подавляющем большинстве поселений, фактических исключенных из этого процесса. Неравномерность российского социального пространства усугубляется не просто неравенством в распределении капитала, но также неравной включенностью территориальных сообществ в процессы капитализации имеющихся у них ресурсов.

Крупнейшие мегаполисы с высоким уровнем жизни населения играют все большую роль в стягивании демографического, инновационного и научно-образовательного потенциала. Происходит активное включение крупных городских региональных агломераций в мировую распределительную систему управления глобальными процессами. Учитывая, что в мегаполисах сегодня проживает 20-30\% населения страны (в том числе с учетом временных жителей), то можно говорить, что для современной России уже не так актуально традиционное разделение между городом и деревней, между индустриальным и аграрным типом общества. Речь идет о разделении социального пространства между постиндустриальным (информационным) обществом и обществом индустриальноаграрным. И даже некоторые региональные столицы воспринимаются сегодня как провинциальные в силу своего незначительного потенциала и малой роли в модернизации окружающего социального пространства. Можно сказать, что идет процесс «разрывания» социального пространства России между точками постиндустриального развития и огромным пространством традиционного, а порой и архаичного общества, имея в виду упадок и деградацию многих локальных сообществ по всей территории страны. Подобная тенденция говорит о неизбежном росте не только экономического и социального, но также культурного и информационного неравенства, об угрозе разрыва ценностного пространства.

Ценностные ориентации имеют значение также для понимания политических процессов, установок и моделей поведения, так как они представляют собой связующее звено между социальным и индивидуальным уровнем. Результаты опроса показывают, что существуют глубокие противоречия, как в структуре, так и во внутреннем содержании политических установок россиян. Если говорить об структуре политических установок, сформулированных в рамках данного исследования в виде кратких лозунгов, то 50\% всех респондентов, в первую очередь поддержали социальную справедливость. Следом идут лозунги: «Россия как великая держава, империя, объединяющая разные народы» (37\%), демократические права и свободы (33\%), сильная жесткая власть и возвращение к национальным традициям (по 30\%), «Россия для русских» $21 \%$, свободный рынок и либеральные ценности (10\%), наконец, сближение с Западом (6\%). Стоит отметить, что демократические права и свободы занимают место между имперскими устремлениями и поддержкой авторитарного режима. Но и внутри блока демократических ценностей существует определенное противоречие. Если учесть, что главными из них являются свобода и равенство, которые по большей части понимаются как набор политических и гражданских прав на свободу и социальных прав на равенство (солидарность), то для российских граждан ценности свободы и равенства существуют не в общем дискурсе демократии, а в своем противопоставлении. Кроме того, они стали приоритетными для разных социальных групп и слоев, а также населения разных типов поселений.

С одной стороны, это указывает на значимость демократии для значительной части россиян, а с другой, на противоречивость ценностной структуры, которая сложилась в общественном сознании, что можно считать следствием целой череды непоследовательных в своих целях и содержании преобразований, которые пережила наша страна за последние несколько десятилетий. Поэтому значение различных ценностей, как и их место в ценностной структуре, стоит рассматривать с учетом этого фактора. Так, поддержка значительной частью населения авторитарного режима в виде сильной жесткой власти, способной навести порядок в стране, идеи России для русских, империи, объединяющей народы, на наш взгляд, во многом можно объяс- 
нить реакцией на ослабление росийского государства на протяжении 1990-х гг.

В максимальной степени объединило жителей всех типов поселений представление о социальной справедливости как наиболее желаемой перспективе для будущего России (см. рис. 4). Достаточно в равной степени жители различных типов поселений поддерживают демократические права и свободы, но также перспективы установления сильной жесткой власти, способной «навести порядок». Поэтому нельзя говорить об отсутствии единого ценностного пространства, но и оно в свою очередь пронизано многими противоречиями. разнообразные идейные и политические установки (консервативные, демократические, либеральные), а жители провинции - более едины в своих консервативных предпочтениях.

Другой объединяющей всех россиян независимо от места проживания установкой является нежелание резких перемен и кардинальных реформ. Так, на вопрос, в чем нуждается страна - «в стабильности» или «переменах и новых экономических, политических реформах», примерно две трети жителей независимо от типа поселений ответили, что стабильность сейчас важнее перемен. Но все-таки надо отметить, что желание стабильности у жителей разных типов поселений

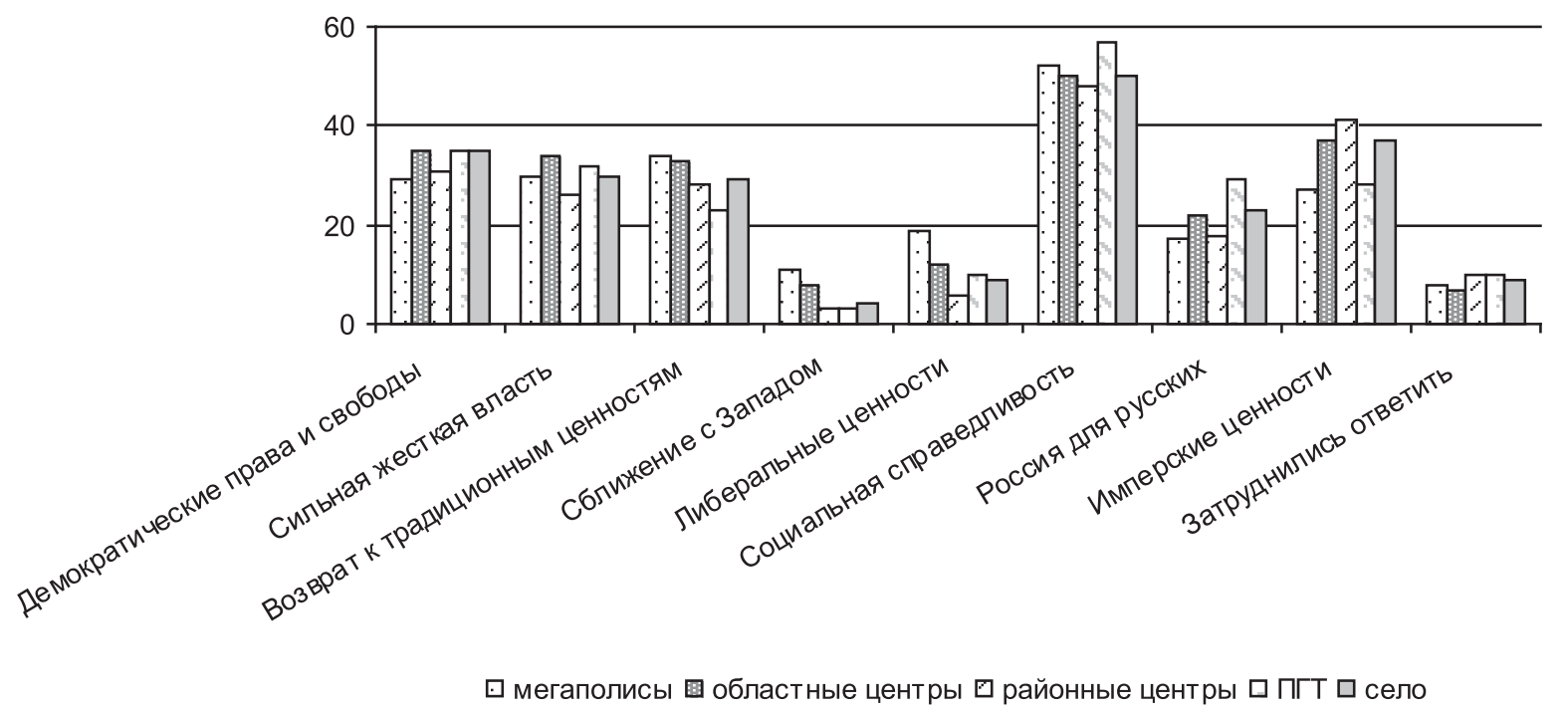

Рис. 4. Представления россиян о желаемом будущем России, \%

Если в том, что касается отношения жителей различных типов поселений к социальной справедливости, демократическим правам и свободам и авторитарной власти, существуют небольшие различия, то в отношении к так называемым либеральным ценностям различие между мегаполисом и остальными типами поселений прослеживается достаточно четко. Либеральные ценности в виде стремления к сободному рынку и сближению с Европой демонстрируют в основном жители мегаполисов, напротив, «великодержавные» и «имперские» ценности поддерживают в основном жители «провинции». Но в то же время жители мегаполисов выступают за возврат к национальным традициям, моральным и религиозным ценностям, проверенных временем. В целом, можно сказать, что жители мегаполисов имеют более имеет разную подоплеку. В известной степени сложилось ценностно-пространственное равновесие: жители мегаполиса стремятся к стабильности на основе либеральных, рыночных ценностей, а жители провинции на коллективистской, уравнительной основе. Но вряд ли такое равновесие можно назвать устойчивым, поскольку оно не сплачивает общество, а напротив, разъединяет его. Жители разных типов поселений убеждены в правильности того образа жизни, который они ведут. И дело здесь не только в пресловутом провинциализме одних и снобизме других, сколько в отсутствии устойчивого общего ценностного пространства, способного снимать противоречия, сдерживать политизацию публичной сферы - культуры, образования, религии. Различия в ценностных ориентациях жителей мегаполиса, с одной стороны, и остальных типов 


\section{Политика и общество 6 (114) • 2014}

поселений, с другой, детерминируют идеологические и политические противоречия. Не случайно, например, в «антимосковских» настроениях присутствует сильная мировоззренческая и политическая составляющая - крайний антилиберализм, антизападничество и иногда - ксенофобия ${ }^{6}$.

Подтверждением тому служат другие парные суждения, которые дают возможность сравнить ценностные ориентиры жителй различных типов поселений в разрезе их отношения к экономической, политической и личной свободе. И здесь мы видим, например, что относительная независимость сельчан по сравнению с жителями малых и средних городов обусловлена именно спецификой жизни на селе, а рост удовлетворенности условиями жизни - не увеличением собственного социальноэкономического потенциала, а ростом оказываемой со стороны государства поддержки. Прежде всего, это проявляется в оценках способности самостоятельно обеспечить себя и свою семью. Если среди жителей мегаполисов такую способность демонстрируют 52\%, то среди жителей села - всего $40 \%$, соответственно 60\% из них высказывают невозможность прожить без поддержки со стороны государства. Динамичность современной жизни больше всего востребована также жителями мегаполисов и меньше всего - жителями поселков городского типа. Личная активность и предприимчивость жителей мегаполиса и поселков городского типа (58\%) противостоят фатализму сельчан (56\%). Значение конкуренции, предприимчивости и активного отстаивания своих прав высоко оценивают, прежде всего, жители областных центров (79\%). В то время как приверженцами традиционных ценностей являются сельчане (54\%), они также меньше жителей других типов поселении готовы жертвовать своими интересами ради общего блага (69\%). Для жителей мегаполисов важно ощущение личной свободы $(83 \%)$, в то время как провинциалам «достаточно» той свободы, которая гарантируется существующими институтами (от 57\% жителей поселков городского типа до $65 \%$ сельчан).

Ценностные ориентации являются значимыми факторами территориального развития. Экстериоризация ценностей, идеалов, образцов поведения - это одновременно их реализация и конструирование. А при-

\footnotetext{
${ }^{6}$ Россман В. В поисках Четвертого Рима: Российские дебаты о переносе столицы. М.: Изд. дом НИУ ВШЭ, 2014. 288 с. C.52.
}

менительно к различным типам поселений - это еще и различные рамки, фреймы, посредством которой индивидуальные и коллективные акторы воспринимают и интерпретируют окружающий их мир с целью планирования социального действия, мобилизации для этого людских и материальных ресурсов, оценки противостоящих им сил и т.д. Так, половина жителей мегаполисов уверены, что люди в последнее время стали более активными, целеустремленными, инициативными, среди жителей областных центров таковых оказалось - 38\%, районных центров - 34\%, поселков городского типа - 29\%, села - 30\%. Жители мегаполисов более оптимистично оценивают готовность людей помогать друг другу, бескорыстие, патриотизм, способность к сотрудничеству, межличностное доверие. Все это проявляется в оценках уровня ответственности россиян за то, что происходит вокруг, в стране в целом. В том, что уровень ответственности россиян за последние годы в целом повысился, уверены 18\% жителей мегаполиса, и только $6 \%$ жителей села.

Таким образом, современное российское общество отличается своей противоречивостью, социальной и территориальной дифференциацией, что обусловливает «наполнение» социального пространства разнообразием ценностно-ориентационных систем, культурных стилей, жизненных форм, коммуникативных действий социальных субъектов. Более того, имеет место своего рода локализация ценностей в социальном пространстве и времени. Если социальное пространство выражает структурность социальной реальности, порядок сосуществования социальных явлений, процессов, институтов, взаимодействия социальных субъектов, то время характеризует подвижность социальной реальности, длительность, сменяющуюся последовательность социальных событий и состояний, ритмичность и упорядоченность происходящих в обществе изменений.

Большинство россиян едины в своем стремлении к социальной справедливости и стабильности. В то же время жителей мегаполиса отличает более выраженная ориентация на индивидуальные, рациональные, активистские ценности, а жителей других типов поселений, напротив, - на коллективистские, нормативные, патерналистские. Ценностная структура мегаполиса также отличается своим разнообразием, одновременным присутствием ценностей и установок либеральной, консервативной и социал-демократической направленности, что предполагает возможность выбора и, следовательно, большей индивидуальной 
свободы. Если мегаполисы концентрируют ресурсы для выработки новых ориентиров, в известной степени формируя в настоящем ценности будущего, то основная часть больших и малых городов и поселков России обеспечивает их устойчивость и преемственность, и лишь баланс этих двух противоположностей гарантирует динамичность и преемственность социального развития.

Модернизация, рассматриваемая как движение к некоторым образцам - результатам, достигнутым развитыми обществами, является сложным и противоречивым процессом. По крайней мере, нет никаких оснований для того, чтобы считать данные образцы идеальными для всех обществ. Каждое общество имеет свои социокультурные, т.е. исторически сложившиеся ценностные основания, позволяющие ему устойчиво развиваться и адаптироваться к переменам. В глобальном мире ценности не являются атрибутами уровня отсталости или, напротив, развития конкретного общества, но сосуществуют в одном социальном пространстве и времени, взаимодействуя или конкурируя с тем, чтобы в целом обеспечить необходимый баланс между стабильностью и развитием.

\section{Библиография:}

1. Зубаревич Н. Модернизация и российское пространство // Доклад о развитии человеческого потенциала в Российской Федерации за 2011 г. / под ред. А. Аузана и С. Бобылева. М.: ПРООН в РФ, 2011. С. 130-141.

2. Куда ведет кризис культуры? Опыт междисциплинарных диалогов / Под общ. ред. И. Клямкина. М.: Новое литературное обозрение, 2011. - 536 с.

3. Медведев Д. Россия, вперед! // Российская газета. № 4995 (171). 2009. 11 сентября.

4. Россман В. В поисках Четвертого Рима: Российские дебаты о переносе столицы. М.: Изд. дом НИУ ВШЭ, 2014. - 288 с.

5. Berman M. All that is Solid Melts Into Air: The Experience of Modernity. NY: Simon and Schuster, 1983. -383 p.
6. Inglehart R., Baker W.E. Modernization, cultural change, and the persistence of traditional values // American sociological review. 2000. Vol.65. February. P.19-51

7. Попов Е.А. Региональная специфика совершенствования человеческого потенциала и социального благополучия населения // NB: Проблемы общества и политики. - 2012. - 2. - C. 118 - 164. URL: http://www.e-notabene.ru/pr/article_234.html

8. Манойло А.В. Ценностные основы управления межцивилизационными конфликтами: российская модель // NB: Международные отношения. 2012. - 1. - C. 32 - 43. URL: http://www.e-notabene. ru/wi/article_279.html

\section{References (transliteration):}

1. Zubarevich N. Modernizatsiya i rossiiskoe prostranstvo // Doklad o razvitii chelovecheskogo potentsiala v Rossiiskoi Federatsii za 2011 g. / pod red. A. Auzana i S. Bobyleva. M.: PROON v RF, 2011. S. 130-141.

2. Medvedev D. Rossiya, vpered! // Rossiiskaya gazeta. № 4995 (171). 2009. 11 sentyabrya.

3. Rossman V. V poiskakh Chetvertogo Rima: Rossiiskie debaty o perenose stolitsy. M.: Izd. dom NIU VShE, 2014. - $288 \mathrm{~s}$.

4. Berman M. All that is Solid Melts Into Air: The Experience of Modernity. NY: Simon and Schuster, 1983. $-383 \mathrm{p}$.

5. Inglehart R., Baker W.E. Modernization, cultural change, and the persistence of traditional values // American sociological review. 2000. Vol.65. February. P.19-51

6. Popov E.A. Regional'naya spetsifika sovershenstvovaniya chelovecheskogo potentsiala i sotsial'nogo blagopoluchiya naseleniya // NB: Problemy obshchestva i politiki. - 2012. - 2. - C. 118-164. URL: http://www.e-notabene.ru/pr/article_234.html

7. Manoilo A.V. Tsennostnye osnovy upravleniya mezhtsivilizatsionnymi konfliktami: rossiiskaya model' // NB: Mezhdunarodnye otnosheniya. - 2012. -1. - C. 32 - 43. URL: http://www.e-notabene.ru/wi/ article_279.html 